\title{
Cane Yield and Juice Volume Determine Ethanol Yield in Sweet Sorghum (Sorghum bicolor L. Moench)
}

\author{
Justice K. Rono ${ }^{1}$, Erick K. Cheruiyot ${ }^{2}$, Jacktone O. Othira ${ }^{1}$ \& Virginia W. Njuguna ${ }^{2}$ \\ ${ }^{1}$ Egerton University, Department of Biochemistry and Molecular Biology, Kenya \\ ${ }^{2}$ Egerton University, Department of Crops, Horticulture and Soil, P. O Box 536-20115, Egerton, Kenya \\ Correspondence: Justice K. Rono, Egerton University, Department of Biochemistry and Molecular Biology, P. O \\ Box 536-20115, Egerton, Kenya. E-mail: ronojustice8@gmail.com
}

Received: September 21, 2018; Accepted: October 3, 2018; Published: October 30, 2018

\begin{abstract}
Sweet sorghum (Sorghum bicolor L. Moench) contains fermentable sugars in the stem that can be converted to ethanol. The current study aimed at evaluating the performance of three sweet sorghum genotypes with five checks and contributes towards availing suitable sweet sorghum for industrial ethanol production. Field studies were carried out in Kenya at varied locations in a randomized complete block design with three replications. Sorghum was harvested at hard dough stage of grain development and evaluated for several stem juice production traits including plant height, cane yield, juice volume, degrees Brix, total, reducing, and non-reducing sugars, and ethanol yield via juice fermentation. Analyses of variance using SAS version 9.1 showed a significant effect of genotype for morphological characters and ethanol yield. Genotype EUSS10 produced the greatest cane (27.4 T/ha) and juice yield $(7806.7 \mathrm{~L} / \mathrm{ha})$ whereas ACFC003/12 recorded the greatest ethanol yield $(423.1 \mathrm{~L} / \mathrm{ha})$. At all sites, EUSS10 had the greatest plant height and days to $50 \%$ heading whereas SS04 had the greatest Brix and total sugar concentration. The greatest grain yield and non-reducing sugar concentration was produced by SS17 and SS21, respectively. Results of this study show that though Brix and total sugars are desirable for ethanol yield, cane yield, and juice volume of sweet sorghum determines the ultimate volume of ethanol produced.
\end{abstract}

Keywords: sweet sorghum, genotypes, stalk juice, ethanol

\section{Introduction}

Sweet sorghum (Sorghum bicolor L. Moench) is an energy crop that produces large quantities of stem juice with readily fermentable sugars that can be converted to ethanol through fermentation. It is a $\mathrm{C}_{4}$ species with high photosynthetic capacity and drought tolerance and therefore, can be cultivated in most temperate and tropical climates (Dalvi et al., 2013). Juice composition affects the amount of ethanol produced (Widianto et al., 2010) and composition is affected by genotype, environment and crop harvesting time (Almodares and Hadi, 2009). Sweet sorghum fermentable sugars in the juice are comparable to that of sugarcane and can be fermented directly into ethanol with an efficiency of more than $90 \%$ (Wu et al., 2010). Sweet sorghum biomass is renewable and can be used for transportation fuel, electricity and chemical production (Ceclan and Pop, 2012). It stands out as the most promising source of raw material for energy and industry among several bioenergy crops (Gosse, 1996). It has rapid growth, higher biomass yield, and wider adaptability than other crops (Pavli et al., 2013) and it is a renewable, cheap and widely available resource (Thanapimmetha et al., 2011).

It is projected that world energy demands will continue to expand by $45 \%$ between 2008 to 2030 , forcing countries to develop alternative fuel sources such as the use of gasoline blended with ethanol for automobile fuel as in India and Brazil (Ratnavathi et al., 2012). Bioethanol fuels produced from agricultural raw materials are considered clean fuels for automobiles and are an alternative to fossil fuels (Imam and Capareda, 2012). Favourable traits of sorghum bioethanol are: less sulphur content in ethanol, a high octane rating and automobile friendly as up to $25 \%$ of the ethanol-petrol mixture can be used without engine modification (Rao et al., 2013). Sweet sorghum fulfils requirements for energy crop proposed by Matsuoka et al. (2014) including being a perennial plant, have welldeveloped agronomic practise, the feedstock is easily and reliably transformed into useful forms of energy and has a favourable cost of production and delivery. Sweet sorghum accumulates more sugars in their stems than other sorghum types as it matures. It consists approximately $75 \%$ cane, $10 \%$ leaves, $5 \%$ grain and $10 \%$ roots when mature (Grassi et al., 2002). 
Sweet sorghum cane juice is mainly comprised of three fermentable sugars; sucrose $(70 \%)$, glucose $(20 \%)$ and fructose $(10 \%)$ which vary depending on variety and environment (Prasad et al., 2007). A high sucrose level at maturity is attributed to low activity of soluble acid invertase and high activity of sucrose synthase in the stem (Tarpley et al., 1994). After flowering, the sucrose content increases while invert sugar decreases (Almodares et al., 2010). Total sugars comprise reducing sugars and non-reducing contained in the stem juice. The total reducing sugars in sweet sorghum is the sum of glucose and fructose contained in stem juice and is used as one of the quality parameters by sugar and ethanol industries (Parrella et al., 2016). Sugars have significant bearing on ethanol yield therefore high sugar yielding genotypes need to be selected (Prasad et al., 2013).

To obtain maximum ethanol yield, sweet sorghum genotypes could be selected for height, Brix, total sugars, nonreducing sugars, reducing sugars, biomass, cane yield, and juice yield as these characters have a positive relationship with ethanol yield (Rani and Umakanth, 2012). Under favourable conditions, sweet sorghum can produce 7682 litres of ethanol per hectare (Murray et al., 2009). In central Greece, the cultivar 'Keller' produced high dry biomass and ethanol yield ranging $21.0-33.6 \mathrm{Mg} / \mathrm{ha}$ and $5120-8390 \mathrm{~L} / \mathrm{ha}$, respectively (SakellariouMakrantonaki et al., 2007). However, in Kenya sweet sorghum has not received much attention and it has not been cultivated commercially on a large scale. The objective of this study was to identify superior sweet sorghum cultivars for ethanol production by evaluating their productivity in different regions of Kenya.

\section{Materials and Methods}

\subsection{Site Description}

Sweet sorghum field experiments were conducted in Kisumu, Siaya and Busia Counties of Kenya. The specific sites were Sinyanya $\left(00^{\circ} 06^{\prime} 68.5^{\prime \prime} \mathrm{S} ; 034^{\circ} 08^{\prime} 66.0^{\prime \prime} \mathrm{E}\right)$ at $1168 \mathrm{~m}$ above sea level (ASL), Masumbi $\left(00^{\circ} 01^{\prime} 73.0^{\prime \prime}\right.$ $\left.\mathrm{N} ; 034^{\circ} 21^{\prime} 87.4^{\prime \prime} \mathrm{E}\right)$ at $1370 \mathrm{~m}$ ASL both in Siaya County, Mundika $\left(00^{\circ} 24^{\prime} 56.6^{\prime \prime} \mathrm{S} ; 034^{\circ} 07^{\prime} 93.1^{\prime \prime} \mathrm{E}\right)$ at $1222 \mathrm{~m}$ ASL in Busia, Nyahera ( $\left.00^{\circ} 0.02^{\prime} 52.78^{\prime \prime} \mathrm{S}, 034^{\circ} 39^{\prime} 03.59^{\prime \prime} \mathrm{E}\right)$ at $1387 \mathrm{~m}$ ASL and Sagam $\left(00^{\circ} 03^{\prime} 20.86^{\prime \prime} \mathrm{N}, 034^{\circ}\right.$ 32' 31.06" E) at $1216 \mathrm{~m}$ ASL both in Kisumu County. The mean annual rainfall and temperature in the area is 1500-1900 mm and 20.9-21.8 ${ }^{\circ} \mathrm{C}$, respectively. Average annual rainfall and temperature of Mundika range 1450$1650 \mathrm{~mm}$ and $21.4-22.3{ }^{\circ} \mathrm{C}$, respectively. Nyahera receives low annual rainfall range: 1220 to $1390 \mathrm{~mm}$ and high mean annual temperature (22.0-22.7) as compared to Sagam. Sagam receives bi-nomial rainfall as to other sites with high rainfall experienced during the first season (February-July) and low second rainy season between August and December. The average annual rainfall in Sagam is $1450-1650 \mathrm{~mm}$ with a mean annual temperature range of 21.2 to $22.8{ }^{\circ} \mathrm{C}$ (Jaetzold et al., 2009). In general, the soil in these areas was sandy clay loam, slightly acidic (pH $=4.4-6.0)$ and was poor in nitrogen (0.1-0.2\%) and phosphorous (5.5-9.8 ppm).

\subsection{Experimental Design}

Eight sweet sorghum genotypes were grown in a randomized complete block design. The new genotypes were EUSS10, EUSS11 and EUSS17 and compared to common ACFC003/21, SS04, SS14, SS21 and SS17 genotypes. Seed sowing was done at the onset of the rains at a seed rate of $8 \mathrm{Kg} / \mathrm{ha}$. Sorghum was sown on 18-March in Sinyanya and Masumbi and 19-March 2014 in Mundika for the first season. Sorghum was sown in the second season on 13-September 2014 for both Mundika and Sagam while Nyahera was planted on 24-September 2014. Genotypes were sown in $0.60 \mathrm{~m}$ rows in plots measuring $4 \times 2.5 \mathrm{~m}$ in a randomized complete block design with three replications. Each plot consisted of four rows of sorghum and the blocks were separated by a $1.5 \mathrm{~m}$ alley. Triple superphosphate fertilizer was applied uniformly to all plots at a rate of $17.2 \mathrm{~kg} / \mathrm{ha}$ at planting. Weeds were controlled manually using hoes three weeks after seedling emergence and sorghum was thinned to a spacing of $0.10 \mathrm{~m}$ within-row and top dressed with calcium ammonium nitrate $(25 \% \mathrm{~N})$ at the rate of $20 \mathrm{~kg} \mathrm{~N} / \mathrm{ha}$. Bird netting was applied soon after the panicles formed to prevent grain predation.

\subsection{Field Data Collection}

Emergence was observed in all plots two weeks after planting and stand counts were conducted at 3-4 leaf stage or later. Days to $50 \%$ heading was determined by calculating the number of days from sowing to when $50 \%$ of the sorghum heads in each plot had produced grains. Sorghum genotypes were monitored until they attained the hard dough stage at which plant height was recorded and crops harvested. Three randomly selected plants from each cultivar in all replicates were used for recording plant height. Plant height was measured from base of stem to tip of panicle and data averaged across three plants.

Harvesting occurred approximately 16 weeks after sowing in the three sites: Masumbi, Mundika and Sinyanya for the first season, and approximately 14 weeks at Sagam and Mundika and 13 weeks at Nyahera for the second season. Plants from the middle two rows of each plot were cut to a stubble height of $0.05 \mathrm{~m}$, leaves were stripped off by hand, and panicles removed using secateurs. Panicles were sun dried, threshed and winnowed manually. 
The grain was weighed and yields in tonnes/ha was calculated. The fresh weight of harvested stalks was determined and stalks were then transported to the laboratory for juice extraction. Juice was extracted with a one roller crusher (FuanLiyuan, China, type YC 80B-4) and strained through a sieve into a juice container. The volume of juice was recorded and degrees Brix (\%) was measured with a hand refractometer (RHB0-90ATC, Fujian, China). After juice extraction, wet bagasse weight was recorded immediately. The bagasse moisture content was determined through modified method of Anwar (2010) where the wet bagasse was kept in microwave at $65^{\circ} \mathrm{C}$ for three days to get constant dry weight. Juice extractability and bagasse moisture was calculated as follows:

Juice extractability $(\%)=[$ weight of juice $(\mathrm{kg}) \div$ fresh cane weight $(\mathrm{kg})] \times 100 \ldots \ldots \ldots \ldots \ldots \ldots \ldots . \ldots \ldots$

Bagasse moisture $(\%)=[($ wet bagasse wt. $(\mathrm{kg})-$ dry bagasse wt. $(\mathrm{kg})) \div$ fresh cane weight $(\mathrm{kg})] \mathrm{x}$

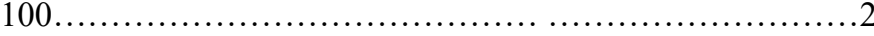

\subsection{Ethanol and Sugar Analysis}

A $100 \mathrm{ml}$ aliquot of extracted juice from each plot was fermented at $35^{\circ} \mathrm{C}$ for four days using Saccharomyces cerevisiae (WT, 1.5\%) and then distilled to obtain ethanol. The active dry brewer's yeast (Angel Yeast Co., Ltd., china) was added directly to sample juice bottles, mixed then sealed and left to ferment. The fermented juice was transferred to rotary evaporator (Buchi Rotavapor R-205) and run for 30 minutes at $78{ }^{\circ} \mathrm{C}$. A refractometer (RFM 3330 , Bellinghant Stanley limited) was used to determine the concentration of ethanol in the distillate. The refractive index of distillate was compared with a standard curve created from absolute ethanol diluted with distilled water to create concentrations of $0,5,10,15,20,25$ and $30 \%$ ethanol. Ethanol was then expressed as $\mathrm{mL}$ of ethanol per litre of fermenting sweet sorghum juice. Ethanol yield $(\mathrm{L} / \mathrm{Ha})$ was estimated from juice yield per hectare of each genotype as follows:

Ethanol yield $(\mathrm{L} / \mathrm{Ha})=\mathrm{L}$ ethanol $\div \mathrm{L}$ juice $\mathrm{x}$ litres of juice per hectare.

Total soluble sugars was determined by phenol-sulphuric acid method (Dubois et al., 1956) whereas reducing sugars was determined by Dinitrosalycyclic acid method (Miller, 1959). Non-reducing sugars was estimated by subtracting reducing sugars from total sugars.

\section{Data Analysis}

Data on cane yield, juice volume, Brix, percent juice extractability, plant height, days to $50 \%$ heading, grain yield, and ethanol yield were subjected to analysis of variance (ANOVA) and means were separated using LSD at $P<0.05$. ANOVA was conducted with SAS software version 9.1 with genotype and environment as fixed effects and replication as random. Data as presented for the genotypes was pooled across locations.

\section{Results and Discussion}

\subsection{Days to 50\% Heading, Plant Height and Green Cane Yield}

Days to $50 \%$ heading, plant height, and cane yield varied by genotype. The time difference between early and late maturing was about 2 weeks. Genotype SS21 was early maturing while EUSS10 was late to mature taking 67 and 82 days, respectively to reach $50 \%$ heading (Table 1). Genotype EUSS10 took a similar number of days to reach $50 \%$ heading with the control SS14, both taking about 4 more days than SS04, EUSS11, EUSS17, and ACFC003/12. EUSS11 and EUSS17 took 3 and 10 more days than the controls SS17 and SS21, respectively to reach $50 \%$ heading. These results are in accordance with findings of Shivani and Sreelakshmi (2014) where days to $50 \%$ flowering were found to range from 51 to 79 days.

Table 1. Days to 50\% heading, plant height and cane yield among eight sweet sorghum genotypes

\begin{tabular}{llll}
\hline Genotype & Days to 50\% heading & Plant height $(\mathrm{m})$ & Cane yield (T/ha) \\
\hline SS04 & $76.4^{\mathrm{bc}}$ & $1.80^{\mathrm{b}}$ & $21.1^{\mathrm{b}}$ \\
SS14 & $81.5^{\mathrm{a}}$ & $1.78^{\mathrm{b}}$ & $22.0^{\mathrm{b}}$ \\
SS21 & $67.4^{\mathrm{d}}$ & $1.53^{\mathrm{c}}$ & $16.1^{\mathrm{c}}$ \\
SS17 & $74.6^{\mathrm{c}}$ & $1.78^{\mathrm{b}}$ & $20.1^{\mathrm{bc}}$ \\
EUSS17 & $77.3^{\mathrm{b}}$ & $1.78^{\mathrm{b}}$ & $20.2^{\mathrm{bc}}$ \\
EUSS10 & $82.1^{\mathrm{a}}$ & $1.95^{\mathrm{a}}$ & $27.4^{\mathrm{a}}$ \\
EUSS11 & $77.8^{\mathrm{b}}$ & $1.70^{\mathrm{b}}$ & $23.5^{\mathrm{ab}}$ \\
ACFC003/12 & $75.8^{\mathrm{bc}}$ & $1.78^{\mathrm{b}}$ & $23.5^{\mathrm{ab}}$ \\
LSD $_{0.05}$ & 2.7 & 12.2 & 4.85 \\
\hline
\end{tabular}


Means followed by the same letter in the same column are not significantly different at 5\% LSD.

Genotype EUSS11 and EUSS17 plant height was similar to that of the controls, but approximately $0.17 \mathrm{~m}$ greater than that of SS21. EUSS10 plant height was greater than all other genotypes and $0.42 \mathrm{~m}$ greater than SS21. Moreover, EUSS10 plant height that was about $0.15 \mathrm{~m}$ taller than SS04, SS14, SS17, and ACFC003/12. In terms of cane yield, EUSS10, EUSS1 1 and Control ACFC003/12 produced about $18.7 \%$ greater cane biomass than SS21. Genotype EUSS17 cane yield was similar to all controls and produced 10.9\% greater cane biomass than SS21. Cane yield is known to be significantly positively correlated with stem diameter and plant height (Audilakshmi et al., 2010) and was so with plant height in this study (Table 4). Plant height and cane yield are known to differ among sorghum cultivars ranging from 1.91 to $2.68 \mathrm{~m}$ and from 54 to $69 \mathrm{~T} / \mathrm{ha}$, respectively (Almodares et al., 2008; Prasad et al., 2013). Late maturing genotypes tend to accumulate high biomass (Ouma and Akuja, 2013) which explains high cane yield produced by EUSS10, which took longer to mature. Similar to sugarcane, an important yield component in sweet sorghum is plant height, which determines harvestable stalk. The longer the stalk, the more likely that genotype will provide greater cane yield, thus it is not surprising that EUSS10 resulted in the greatest yield while SS21 gave the least.

\subsection{Juice Yield, Extractability, Bagasse Moisture and Grain Yield}

There were no differences among sorghum genotypes for percent extractability and bagasse moisture, which averaged 42.9 and $38.8 \%$, respectively (Table 2). The juice yield was influenced by sorghum genotype. EUSS10 had a greater juice volume of $7806.7 \mathrm{~L} / \mathrm{ha}$ than all other genotypes while SS21 produced the least juice volume (3098.6 L/ha) of all genotypes. All other genotypes were similar with juice volume ranging from 4635 to 5835 L/ha.

Table 2. Sweet sorghum genotype effect on juice yield, extractability, bagasse moisture and grain yield

\begin{tabular}{lllll}
\hline Genotype & Juice yield (L/ha) & Extractability (\%) & Bagasse moisture content (\%) & Grain yield (T/ha) \\
\hline SS04 & $5116^{\mathrm{b}}$ & $41.6^{\mathrm{a}}$ & $38.6^{\mathrm{a}}$ & $2.07^{\mathrm{ab}}$ \\
SS14 & $5835^{\mathrm{b}}$ & $43.6^{\mathrm{a}}$ & $37.1^{\mathrm{a}}$ & $1.56^{\mathrm{bc}}$ \\
SS21 & $3098^{\mathrm{c}}$ & $41.4^{\mathrm{a}}$ & $38.9^{\mathrm{a}}$ & $1.36^{\mathrm{bc}}$ \\
SS17 & $4635^{\mathrm{b}}$ & $43.5^{\mathrm{a}}$ & $37.0^{\mathrm{a}}$ & $2.60^{\mathrm{a}}$ \\
EUSS17 & $5018^{\mathrm{b}}$ & $42.9^{\mathrm{a}}$ & $37.0^{\mathrm{a}}$ & $2.51^{\mathrm{a}}$ \\
EUSS10 & $7807^{\mathrm{a}}$ & $44.8^{\mathrm{a}}$ & $38.3^{\mathrm{a}}$ & $1.31^{\mathrm{c}}$ \\
EUSS11 & $5794^{\mathrm{b}}$ & $45.7^{\mathrm{a}}$ & $35.9^{\mathrm{a}}$ & $2.40^{\mathrm{a}}$ \\
ACFC003/12 & $5455^{\mathrm{b}}$ & $39.8^{\mathrm{a}}$ & $39.7^{\mathrm{a}}$ & $2.42^{\mathrm{a}}$ \\
LSD $_{0.05}$ & 1488 & 6.0 & 4.6 & 0.75 \\
\hline
\end{tabular}

Means followed by the same letter in the same column are not significantly different at 5\% LSD

Grain yield was badly damaged by birds in Sinyanya and was not harvested. At all sites, grain yield was affected by genotype. These results are in harmony with findings of Abdalla and Gamar (2011) and Showemimo (2007) who found a significant difference between sorghum lines for grain yield in Sudan. Interestingly, EUSS10 produced the lowest grain yield (1.3 T/ha) which was similar to controls SS14 and SS21 and about $22.5 \%$ lower than other genotypes. From this study, it is evident that considerable juice was lost with bagasse. The single roller press used for juice extraction is inefficient and would not be suitable for commercial production. Irrespective, the rankings of the genotypes for juice yield is still valid because the amount of juice retained by the bagasse was similar across genotypes.

\subsection{Juice Brix, Sugars, and Ethanol Yield}

EUSS11 Brix was similar to that of all control genotypes while EUSS17 Brix was similar to all controls except that of SS04 (Table 3). SS04 Brix was 1.4\% greater than that of EUSS17. Meanwhile, EUSS10 Brix was less than that of all genotypes. Genotype SS04 recorded greatest percent total sugar (11.1\%) and it was similar to that of SS21 and EUSS17. EUSS10 had the least total sugar that was approximately 2 percentage points less than the three control genotypes. Reducing sugar did not differ between genotypes and ranged from 1.4 to $1.9 \%$. Lowest non-reducing sugar (sucrose) was recorded by EUSS10 and it was similar to only that of SS14 and about 1.5\% lower than other genotypes. Genotype ACFC003/12 and EUSS10 produced the greatest ethanol yields (423 and $420 \mathrm{~L} / \mathrm{ha}$, respectively), but yields were similar to those of SS04, SS14, EUSS17, and EUSS11. Ethanol yields of EUSS10 and ACFC003/12 were about 83\% greater than that of the least yielding genotype SS21 and about 37\% greater than that of SS17. 
Table 3. Brix, total sugar, reducing sugar, non-reducing sugar and ethanol yield among eight sweet sorghum genotypes

\begin{tabular}{llllllll}
\hline Genotype & $\begin{array}{l}\text { Brix } \\
(\%)\end{array}$ & $\begin{array}{l}\text { Total } \\
(\%)\end{array}$ & $\begin{array}{l}\text { sugars } \\
(\%)\end{array}$ & $\begin{array}{l}\text { seducing } \\
(\%)\end{array}$ & $\begin{array}{l}\text { sugar-reducing } \\
(\%)\end{array}$ & $\begin{array}{l}\text { Ethanol } \\
(\mathrm{L} / \mathrm{ha})\end{array}$ & yield \\
\hline SS04 & $16.8^{\mathrm{a}}$ & $11.11^{\mathrm{a}}$ & $1.86^{\mathrm{a}}$ & $8.16^{\mathrm{a}}$ & $349^{\mathrm{ab}}$ \\
SS14 & $16.0^{\mathrm{ab}}$ & $9.87^{\mathrm{c}}$ & $1.87^{\mathrm{a}}$ & $7.39^{\mathrm{ab}}$ & $376^{\mathrm{ab}}$ \\
SS21 & $15.5^{\mathrm{ab}}$ & $10.78^{\mathrm{ab}}$ & $1.93^{\mathrm{a}}$ & $8.56^{\mathrm{a}}$ & $230^{\mathrm{c}}$ \\
SS17 & $15.3^{\mathrm{b}}$ & $10.21^{\mathrm{bc}}$ & $1.86^{\mathrm{a}}$ & $8.22^{\mathrm{a}}$ & $306^{\mathrm{bc}}$ \\
EUSS17 & $15.4^{\mathrm{b}}$ & $10.27^{\mathrm{abc}}$ & $1.85^{\mathrm{a}}$ & $7.91^{\mathrm{a}}$ & $359^{\mathrm{ab}}$ \\
EUSS10 & $12.1^{\mathrm{c}}$ & $8.24^{\mathrm{d}}$ & $1.43^{\mathrm{a}}$ & $6.27^{\mathrm{b}}$ & $420^{\mathrm{a}}$ \\
EUSS11 & $16.1^{\mathrm{ab}}$ & $9.98^{\mathrm{bc}}$ & $1.85^{\mathrm{a}}$ & $7.94^{\mathrm{a}}$ & $413^{\mathrm{ab}}$ \\
ACFC003/12 & $16.5^{\mathrm{ab}}$ & $9.68^{\mathrm{c}}$ & $1.54^{\mathrm{a}}$ & $7.81^{\mathrm{a}}$ & $423^{\mathrm{a}}$ \\
LSD $_{0.05}$ & 1.3 & 0.87 & 0.52 & 1.32 & 113 \\
\hline
\end{tabular}

Means followed by the same letter in the same column are not significantly different at $5 \%$ LSD

Genotypic differences for juice volume, Brix, and ethanol yield have also been reported (Reddy et al., 2011; Reddy et al., 213; Soleymani et al., 2013; Elangovan et al., 2014; Reddy et al., 2014). Low ethanol yields recorded by control SS21 was due to its short height and early maturity hence accumulating low biomass and producing low cane and juice yield across the sites. Cane yield (19.6-34.2 T/ha) and juice extractability (48.5-54.7\%) obtained from six sweet sorghum varieties by El-Geddawy et al. (2014). is comparable to results from our study. However, they recorded higher Brix (17.5-21.8\%) and plant height (223.4-411.3 cm). The sugar content of the juice obtained from the study was within the range obtained for other studies (Ritter et al. (2004; Datta Mazumdar et al., 2012). Sweet sorghum hybrids have been developed that produce higher cane $(47 \mathrm{~T} / \mathrm{ha})$ and ethanol yield $(1940 \mathrm{~L} / \mathrm{ha})$ than common genotypes (Sawargaonkar and Wani, 2016). Higher cane and ethanol yield reported by Atokple et al. (2014) in Ghana than in the present could be attributed to difference in soils, climatic conditions and the stalk variety.

\subsection{Correlation among Stem Traits}

Ethanol yield, cane yield, juice yield, plant height and grain yield were all positively correlated at $\mathrm{P}<0.001$. This result is consistent with findings of Wang et al. (2012). Juice yield was positively correlated with days to $50 \%$ heading at $\mathrm{P}<0.01$, whereas Brix was positively correlated $(\mathrm{P}<0.001)$ with total sugar and non-reducing sugar. A negative relationship was observed between extractability and non-reducing at $\mathrm{P}<0.05$; plant height and total sugar at $\mathrm{P}<0.001$ and reducing sugar and non-reducing sugar at $\mathrm{P}<0.05$. Fermentable sugars form a major component of total soluble solids in sweet sorghum stem juice thus a positive linear correlation between Brix and total sugars is expected. Sucrose (non-reducing sugar) is the predominant stalk sugar in sweet sorghum and is converted to reducing sugars (glucose and fructose) by invertase, thus a negative relationship is likely to be observed between reducing and non-reducing sugar. In this study, the greatest ethanol yielding genotypes also had the greatest cane yield, juice yield, and plant height. Thus, tall sorghum genotypes producing high cane yield should be selected for planting to enhance juice yield and consequently high ethanol production.

Genotype EUSS10 produced the lowest Brix values and total sugar yield. However, it yielded the greatest cane and juice volume, and produced ethanol yields that were similar to ACFC003/12. This result highlights the interplay of sugar concentration and juice yield and indicates clearly that sugar yield per hectare (juice yield $\mathrm{x}$ sugar concentration) is more indicative of high ethanol yields than sugar concentration alone. In this case, low sugar concentration in EUSS10 was compensated by higher yields of cane and cane juice resulting in a higher sugar yield for ethanol fermentation. Brix values indicate total soluble solids in juice extract and are positively correlated with sugars, and ethanol yield. According to Erickson et al. (2011), a low Brix value is generally associated with greater fresh biomass production. In their study, they found a negative correlation between Brix values in juice and fresh biomass yield of sweet sorghum genotypes grown in the year 2009 and 2010. Genotype EUSS10 had highest cane yield and lowest Brix concurring with their findings. Further

Genotypes that had a high cane and juice yield, and plant height produced high ethanol yield. These traits together with days to $50 \%$ heading were found to be positively correlated with ethanol yield as reported by Prasad et al. (2013) and Rani and Umakanth (2012). Genotypes that took more time to mature accumulated more biomass, which translated to high juice and consequently high ethanol yield. This is similar to Houx and Fritschi (2013) who also found that the late maturing 'M 81E' genotype had the lowest Brix, but greatest juice yield that resulted 
in high sugar yields and subsequent ethanol yields that were among the greatest of 12 genotypes evaluated. However, Sweet sorghum should be harvested before stem sugars are converted to starch and stored in grain.

Table 4. Correlation among stem traits and grain yield

\begin{tabular}{|c|c|c|c|c|c|c|c|c|c|c|c|}
\hline & $\begin{array}{l}\text { Cane } \\
\text { yield } \\
(\mathrm{T} / \mathrm{ha})\end{array}$ & $\begin{array}{l}\text { Juice yield } \\
\text { (L/ha) }\end{array}$ & $\begin{array}{l}\text { Ethanol } \\
\text { yield } \\
\text { (L/ha) }\end{array}$ & $\begin{array}{l}\text { Brix } \\
(\%)\end{array}$ & $\begin{array}{l}\text { Extractability } \\
(\%)\end{array}$ & $\begin{array}{l}\text { Plant } \\
\text { height } \\
(\mathrm{cm})\end{array}$ & $\begin{array}{l}\text { Days to } \\
50 \% \\
\text { heading }\end{array}$ & $\begin{array}{l}\text { Grain } \\
\text { yield } \\
(\mathrm{L} / \mathrm{ha})\end{array}$ & $\begin{array}{l}\text { Total } \\
\text { sugar (\%) }\end{array}$ & $\begin{array}{l}\text { Reducing } \\
\text { sugar (\%) }\end{array}$ & $\begin{array}{l}\text { Non- } \\
\text { reducing } \\
\text { sugar (\%) }\end{array}$ \\
\hline $\begin{array}{l}\text { Cane yield } \\
(\mathrm{T} / \mathrm{ha})\end{array}$ & - & $0.9099^{* * *}$ & $0.8228^{* * *}$ & $\begin{array}{l}- \\
0.1331^{\mathrm{ns}}\end{array}$ & $0.0304^{\mathrm{ns}}$ & $0.6867^{* * * *}$ & $0.0885^{\mathrm{ns}}$ & $0.3677^{* * * *}$ & $-0.2050^{\mathrm{ns}}$ & $-0.2597^{\mathrm{ns}}$ & $-0.0148^{\mathrm{ns}}$ \\
\hline $\begin{array}{ll}\text { Juice } & \text { yield } \\
\text { (L/ha) } & \\
\end{array}$ & & - & $0.8431^{* * *}$ & $\begin{array}{l}- \\
0.1608^{\mathrm{ns}}\end{array}$ & $-0.0008^{\mathrm{ns}}$ & $0.6356^{* * *}$ & $0.2289^{* *}$ & $0.3790^{* * *}$ & $-0.2043^{\mathrm{ns}}$ & $-0.1927^{\mathrm{ns}}$ & $-0.0850^{\mathrm{ns}}$ \\
\hline $\begin{array}{l}\text { Ethanol yield } \\
(\mathrm{L} / \mathrm{ha})\end{array}$ & & & - & $\begin{array}{l}- \\
0.0252^{\mathrm{ns}}\end{array}$ & $0.0011^{\mathrm{ns}}$ & $0.5048^{* * *}$ & $0.0194^{\mathrm{ns}}$ & $0.3217^{* * * *}$ & $-0.1679^{*}$ & $-0.1409^{\mathrm{ns}}$ & $-0.0174^{\mathrm{ns}}$ \\
\hline Brix (\%) & & & & - & $0.1315^{\mathrm{ns}}$ & $-0.4846^{* * * *}$ & $0.0221^{\mathrm{ns}}$ & $0.1091^{\mathrm{ns}}$ & $0.5640^{* * *}$ & $0.0377^{\mathrm{ns}}$ & $0.4545^{* * *}$ \\
\hline $\begin{array}{l}\text { Extractability } \\
(\%)\end{array}$ & & & & & - & $-0.1051^{\mathrm{ns}}$ & $0.1367^{\mathrm{ns}}$ & $0.1286^{\mathrm{ns}}$ & $-0.0904^{\mathrm{ns}}$ & $0.1481^{\mathrm{ns}}$ & $-0.2416^{*}$ \\
\hline $\begin{array}{l}\text { Plant height } \\
(\mathrm{cm})\end{array}$ & & & & & & - & $-0.0579^{\mathrm{ns}}$ & $0.1170^{\text {ns }}$ & $-0.3374^{* * * *}$ & $-0.2259^{\mathrm{ns}}$ & $-0.1156^{\mathrm{ns}}$ \\
\hline $\begin{array}{l}\text { Days to } 50 \% \\
\text { heading }\end{array}$ & & & & & & & - & $0.1873^{*}$ & $-0.0119^{\text {ns }}$ & $-0.1533^{\mathrm{ns}}$ & $-0.1403^{\text {ns }}$ \\
\hline $\begin{array}{l}\text { Grain yield } \\
(\mathrm{L} / \mathrm{ha})\end{array}$ & & & & & & & & - & $-0.0436^{\mathrm{ns}}$ & $0.0942^{\mathrm{ns}}$ & $-0.1334^{\text {ns }}$ \\
\hline $\begin{array}{l}\text { Total sugar (\%) } \\
\text { Reducing sugar } \\
(\%)\end{array}$ & & & & & & & & & - & $\begin{array}{l}0.0374^{\mathrm{ns}} \\
-\end{array}$ & $\begin{array}{l}0.9474^{* * *} \\
-0.2844^{*}\end{array}$ \\
\hline $\begin{array}{l}\text { Non-reducing } \\
\text { sugar (\%) }\end{array}$ & & & & & & & & & & & - \\
\hline
\end{tabular}

\section{Conclusions}

This study demonstrates that although Brix (\%) and total sugar concentration are desirable traits in sorghum stalk juice, juice volume and subsequent sugar yield is the main determinant for ethanol yield. All three genotypes (EUSS10, EUSS11, EUSS17) evaluated produced ethanol yields that were greater than or equal to the genotypes currently grown in Kenya. These three genotypes show characteristics that justify further research to develop management practices to optimize ethanol production and determine if any pests may limit further use.

\section{Conflict of Interests}

The authors have not declared any conflict of interests.

\section{References}

Abdalla, H. M., \& Gamar, Y. A. (2011). Climate change: Selection of sorghum genotypes with wide adaptation, AG-17, for rain-fed areas of Sudan. Int. J. AgriSci., 1, 144-155.

Almodares, A, \& Hadi, M. R. (2009). Production of bioethanol from sweet sorghum: A review. Afri. J. Agric. Res., 4, 772-780.

Almodares, A., Ranjabar, M., \& Hadi, M. R. (2010). Effect of nitrogen treatments and harvesting stages on the aconitic acid, invert sugar and fiber in sweet sorghum cultivars. J. Env. Biol., 31, 1001-1005.

Almodares, A., Taheri, R., \& Adeli, S. (2008). Stalk yield and carbohydrate composition of sweet sorghum cultivars and lines at different growth stages. J. Malesian Appl. Biol., 37, 31-36.

Anwar, S. I. (2010). Determination of moisture content of bagasse of jaggery unit using microwave oven. J. Eng. Sci.Technol., 5(4), 472-478.

Atokple, I. D., Oppong, G., \& Chikpah, S. (2014). Evaluation of Grain and Sugar Yields of Improved Sweet Sorghum (Sorghum bicolor) Varieties in the Guinea Savanna Zone of Ghana. Pinnacle Agri. Res. Manage, 2, $1-9$

Audilakshmi, S., Mall, A. K., Swarnalatha, M., \& Seetharama, N. (2010). Inheritance of sugar concentration in 
stalk, sucrose content, stalk and juice yield in sorghum. Biomass Bioenerg, 34, 813-820. https://doi.org/10.1016/j.biombioe.2010.01.025

Ceclan, R. E., Pop, A., \& Ceclan, M. (2012). Studies concerning the integrated use of sweet sorghum for bioethanol production in Romania. Chem. Eng. Trans., 29, 877-882.

Dalvi, U. S., Charan, U. D., Shinde, M. S., \& Gaikwad, A. R. (2013). Seasonal impact on biomass, juice quality and sugar attributes of sweet sorghum. J. Acad. and Indus., 1, 432-434.

Datta, M. S., Poshadri, A., Srinivasa, R. P., Ravinder, R. C. H., \& Reddy, B. V. S. (2012). Innovative use of Sweet sorghum juice in the beverage industry. Int. Food Res. J., 19(4), 1361-1366.

Dubois, M., Gilles, K. A., Hamilton, J. K., Rebers, P., \& Smith, F. (1956). Colorimetric method for determination of sugars and related substances. Anal. Chem., 28, 350-356. https://doi.org/10.1021/ac60111a017

Elangovan, M., Babu, P. K., Seetharama, N., \& Patil, J. V. (2014). Genetic diversity and heritability characters associated sweet sorghum (Sorghum bicolor L. Moench). Sugar Tech., 16, 200-210. https://doi.org/10.1007/s12355-013-0262-5

El-Geddawy, D. I., Awad, N. M., \& Moustafa, M. I. (2014). Lighting spot around yield and technological characteristics of some sweet sorghum varieties. Int. J. Curr. Microbiol. App. Sci., 3, 843-850.

Erickson, J. E., Helsel, Z. R., Woodward, K. R., Vendramini, J. M., Wang, Y., Sollenberger, L. E., \& Gilbert, R. A. (2011). Planting date affects biomass and Brix of sweet sorghum grown for biofuel across florida. Agron. J., 103, 1827-1834. https://doi.org/10.2134/agronj2011.0176

Gosse, G. (1996). Overview on the different routes for industrial utilization of sorghum. First European seminar on sorghum for energy and industry, Tolouse, France. Pp. 1-3.

Grassi, G., Qiong, Z., Grassi, A., Fjallstrom, T., \& Helm, P. (2002). Small-scale modern autonomous bioenergy complexes: development instrument for fighting poverty and social exclusion in rural villages. Proceedings of $12^{\text {th }}$ European Conference on Biomass for Energy, Industry and Climate Change; 2002 June $17^{\text {th }}-21^{\text {st }}$; Amsterdam, Netherlands.

Houx, J. H., \& Fritschi, F. B. (2013). Influence of midsummer planting dates on ethanol production potential of sweet sorghum. Agron. J., 105, 1761-1768. https://doi.org/10.2134/agronj2013.0083

Imam, T., \& Capareda, S. (2012). Fermentation kinetics and ethanol production from different sweet sorghum varieties. Int. J. Agric. Biol. Eng., 4, 33-40.

Jaetzold, R., Schmidt, H., Hornetz, B., \& Shisanya, C. (2009). Farm management handbook of Kenya, vol II, part A: Natural conditions and farm management information (West Kenya, Nyanza Province), 15-19.

Matsuoka, S., Kennedy, A. J., Dos, S. E. G., Tomazela, A. L., \& Rubio, L. C. (2014). Energy cane: its concepts, development, characteristics and prospects. Adv. Bot., 2014, 1-13. https://doi.org/10.1155/2014/597275

Miller, G. L. (1959). Use of Dinitro Salicylic acid reagent for determination of reducing sugar. Anal. Chem., 31, 426-428. https://doi.org/10.1021/ac60147a030

Murray, S. C., Rooney, W. L., Martha, T., Hamblin, M. T., Sharon, E., Mitchell, S. E., \& Kresovich, S. (2009). Sweet sorghum genetic diversity and association mapping for Brix and height. Plant Genome, 2, 48-62. https://doi.org/10.3835/plantgenome2008.10.0011

Ouma JP, Akuja TE (2013). Agronomic and morphological performance of sorghum (Sorghum bicolor) for the dry highlands of Kenya. J. Appl. Biosci., 63, 4720-4726. https://doi.org/10.4314/jab.v63i1.87246

Parrella, R. A. D., Souza, V. F. D., \& Parrella, N. N. L. (2016). Maturation curves of sweet sorghum genotypes. Scienc.Agrotec, 40(1), 46-56. https://doi.org/10.1590/S1413-70542016000100004

Pavli, Q. I., Vlachos, C. E., Kalloniati, C., Flemetakis, E., \& Skaracis, G. N. (2013). Metabolite profiling reveals the effect of drought on sorghum (Sorghum bicolor L. Moench) metabolism. Plant Omics J., 6, 371-376.

Prasad, S., Kumar, A., \& Muralikrishna, K. S. (2013). Assessment of ethanol yield associated characters in sweet sorghum. Maydica, 58, 299-303.

Prasad, S., Singh, N., Jain, N., \& Hoshi, H. C. (2007). Ethanol production from sweet sorghum syrup for utilization as automotive fuel in India. Energy Fuel, 21, 2415-2420. https://doi.org/10.1021/ef060328z

Rani, C., \& Umakanth, A. V. (2012). Genetic variation and trait inter-relationship in F1 hybrids of sweet sorghum (Sorghum bicolor L. Moench). J. Trop. Agric., 50, 80-83. 
Rao, S. S., Patil, J. V., Prasad, P. V., Reddy, D. S., Mishra, J. S., Umakanth, B. V., Reddy, B. V., \& Kumar, A. A. (2013). Sweet sorghum planting effects on stalk yield and sugar quality in semi-arid tropical environments. Agron. J., 105, 1458-1465. https://doi.org/10.2134/agronj2013.0156

Ratnavathi, C. V., Kumar, S. R., Kumar, B. S., Krishna, D. G., \& Patil, J. V. (2012). Effect of Time of Planting on Cane Yield and Quality Characters in Sweet Sorghum. J. Sustain. Bioenergy Syst., 2, 1-9. https://doi.org/10.4236/jsbs.2012.21001

Reddy, B. V., Rao, P. S., \& Kumar, C. G. (2013).Sweet sorghum: From theory to practise. In characterization of improved sweet sorghum cultivar, pp: 1-15.Rao, P. S. and C. Springer Briefs in agriculture, Springer, India.

Reddy, P. S., Rao, P. S., Rathore, A., Reddy, B. V., \& Panwar, S. (2011). Application GGE biplot and AMMI model to evaluate sweet sorghum (Sorghum bicolor L. Moench) hybrids for genotype $\dot{x}$ environment interactions and seasonal adaptation. Indian J. Agric. Sci., 81, 438-444.

Reddy, P. S., Reddy, B. V., \& Rao, P. S. (2014). Genotype by sowing date interaction effects on sugar yield components in sweet sorghum (Sorghum bicolor L. Moench). SABRAO J. Breed. Genet., 46, 241-255.

Ritter, K., Chapman, S., Jordan, D., Godwin, I., \& McIntyre, C. L. (2004, September). Investigating the use of sweet sorghum as a model for sugar accumulation in sugarcane. In New directions for a diverse planet: Proceedings of the 4th International Crop Science Congress (Vol. 26).

Sawargaonkar, G. L., \& Wani, S. P. (2016). Nitrogen response of sweet sorghum genotypes during rainy season. Curr. Sci., 110(9), 1699.

Shivani, D., \& Sreelakshmi, C. (2014). Interaction and stability analysis in Rabi sorghum. J. Global Biosci., 3, 626-632.

Showemimo, F. A. (2007). Grain yield response and stability indices in sorghum (Sorghum bicolor L. Moench). Commun. Biometry Crop Sci., 2, 68-73.

Soleymani, A., Almodaresand, A., \& Shahrajabian, M. H. (2013). The effect of increase in plant density on stem yield, sucrose content and ethanol yield in two sweet sorghum cultivars. Int. J. Agron. Plant Prod., 4, 642646.

Tarpley, L., Lingle, S. E., Vietor, D. M., Andrews, D. L., \& Miller, F. R. (1994). Enzymatic control of non-structural carbohydrate concentration in stems and panicles of sorghum. Crop Sci., 34, 446-552. https://doi.org/10.2135/cropsci1994.0011183X003400020026x

Thanapimmetha, A., Vuttibunchon, K., Saisriyoot, M., \& Srinophakun, P. (2011). Chemical and Microbial hydrolysis of sweet sorghum bagasse for ethanol production. World Renewable Energy Congress, Linkoping, Sweden. 8-13 ${ }^{\text {th }}$ May, Pp. 389-397. https://doi.org/10.3384/ecp11057389

Wang, M., Xin, Z., Tonnis, B., Farrell, G., Pinnow, D., Chen, Z., Davis, J., Yu, J., Hung, Y., \& Pederson, G. A. (2012). Evaluation of sweet sorghum as a feedstock by multiple harvests for sustainable bioenergy production. J. Sustain. Bioenergy Syst., 2, 122-137. https://doi.org/10.4236/jsbs.2012.24019

Widianto, D., Arofatullah, A., Yuwono, T., \& Prijambada, I. D. (2010). Ethanol production by fermentation of various sweet-stalk sorghum juices using various yeast strains. I. J. Biotech., 15, 86-92.

Wu, X., Staggenborg, S., Propheter, J. L., Rooney, W. L., Yu, J., \& Wang, D. (2010). Features of sweet sorghum juice and their performance in ethanol fermentation. Ind. Crop. Prod., 31, 164-170. https://doi.org/10.1016/j.indcrop.2009.10.006

\section{Copyrights}

Copyright for this article is retained by the author(s), with first publication rights granted to the journal.

This is an open-access article distributed under the terms and conditions of the Creative Commons Attribution license (http://creativecommons.org/licenses/by/4.0/). 